\title{
Human Resources (HR) In Education Management
}

\author{
Bahdin Nur Tanjung \\ Universitas Muhammadiyah Sumatera Utara, Indonesia \\ bahdinnur@umsu.ac.id
}

\begin{abstract}
Human resources (HR) has a significant role in every activity in an institution including educational institutions. Human resources (HR) must be able to be managed or managed properly in accordance with their functions so that these human resources $(H R)$ can play a role in accordance with their duties and functions in the institution they are in. Human resource management is a very important aspect in the education process in general. Therefore functions in the management of human resources must be carried out optimally so that the needs relating to the goals of individuals, organizations / institutions, organizations or institutions can be achieved. Besides that, with good human resource management procedures, it is expected that the shortcomings and problems faced by the Indonesian nation, which are related to competitiveness, can be overcome.
\end{abstract}

Keywords

human resources;

leadership;

educational

organizations

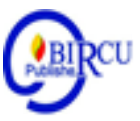

\section{Introduction}

The development of science and technology today is growing along with the progress of the times. The existence of the development of science and technology has a major effect on lifestyles and human habits, especially if there is no filter or filter of various things as an impact of the development of science and technology, it will certainly affect the performance of every human being, including in education. Human resources have a big role in the implementation of education. Education which is a process cannot be separated from the role of human resources because one of the important aspects is human resources themselves. In addition, humans always play an active role in every activity of the organization, because humans sometimes become planners, actors, and determinants of the realization of organizational goals. Objectives are not possible without the active role of employees even though the tools of the company are sophisticated. This also applies in the world of education, because more specifically the learning process played by educators cannot be replaced by technology. To make human resources function more effectively and efficiently, good management is needed, starting from planning to the final stage in the management function. Discussing the existence of human resources (HR) in educational organizations is a natural thing because in the process of education human resources (HR) have a large role both in terms of administrative and operational. Human resources (HR) need to be managed properly so that they can play roles according to their functions. That is why the need for human resource management (HR).

The word management comes from Latin, namely from the origin of the word manus which means hand and agree which means to do. The words are combined into manager verbs, which mean handling. Managers is translated into English in 
the form of verbs to manage, with the noun management, and managers for those who carry out management activities. Finally, management is translated into English into management and management1. Management comes from the word "to manage" which means to manage, regulate, drive, control, handle, manage, organize, run, carry out, lead2. In the book written by Made Pidarta explained that in Terry's opinion, "management is a district process consisting of planning, organizing, actuating, and controlling, performed to determine and accomplished stated objectives by the use of human beings and other resources" management is a process certain consisting of planning, organizing, mobilizing, and supervising, which is carried out to determine and achieve the goals set by using human / people and other resources. Marry Parker Follet defines management as the art of getting work done through people. This definition means that a manager is tasked with managing and directing others to achieve organizational goals. James Stoner Ricky defines management as a process of planning, organizing, leadership and controlling the efforts of organizational members and the use of all organizational resources to achieve the goals set effectively and efficiently.

Harold Koonts and CirylO'Donel define management as an effort to achieve a certain goal through the activities of others. Thus the manager coordinates the number of activities of others which include planning, organizing, placement, direction, and control. In addition, Andrew F. Sikula argues that management is generally associated with the activities of planning, organizing, controlling, placing, directing, motivating, communicating and making decisions by each organization with the aim of coordinating the various resources owned by the company so that an efficient product or service will be produced. Suhardan et.al argued that education management is a management process in implementing educational tasks by efficiently utilizing all resources to achieve goals effectively. According to Mulyasa, education management is a system of management and structuring of educational resources, such as education personnel, students, communities, curriculum, funds (finance), educational facilities and infrastructure, governance and educational environment. Therefore in the study of learning management or education management is divided into two groups namely. (a) Administrative management that focuses on planning, organization, guidance, direction, coordination and supervision activities, and communication. (b) Operational management that focuses on administrative, staffing, financial, and school relations with the community.

Educational management is an arrangement in the field of educational work carried out through planning, organizing, staffing, coaching, coordinating, communicating, motivating, budgeting, controlling, controlling, controlling, evaluating and reporting activities systematically to achieve quality educational goals. From the various statements above, a conclusion can be drawn that education management is a system of management and utilization of all educational resources to carry out systematic and systemic cooperation processes so that effective education implementation can be realized and efficient in order to realize the national education goals that have been aspired. 


\section{Review of Literature}

\subsection{Human Resource Management (HR)}

In English, Human Resource Management (HR) is called "Human Resource man agreement" which in short becomes HRM.8 Human beings are part of the resources needed by the company / organization. However, there are still many management policies that do not pay attention to the importance of the role of human resources, so from this understanding I can analyze that the policy company still does not pay attention to the interests of human resources. Human resource management is a very important aspect in the education process in general. Therefore functions in the management of human resources must be carried out optimally so that the needs relating to individual, organizational / institutional, organizational or institutional goals can be achieved. Besides that, with good human resource management procedures, it is expected that the shortcomings and problems faced by the Indonesian people, who are related to competitiveness, can be overcome.

Here are some expert views on the concept of personnel management: (a) Edwin B. Flippo, stated that personnel management is the process of planning, organizing, directing and controlling the procurement of labor, development, compensation, integration, maintenance and termination of employment with a view to achieving the goals or objectives of individuals, organizations, and the community their work or work relationship. (b). Andrew F Sikula, stated that staffing administration is the placement of people into an organization / institution. Implementation of human labor is the procurement, maintenance, placement, indoctrination, training and education of human resources. (c) John B. Miner and Mary Green Miner, stated that personnel management is defined as a process of developing, implementing, and evaluating policies, procedures, methods, and programs relating to individual employees in the organization. Michel J. Julius, stated that personnel management is the field of management which is related to the planning, organizing, and controlling various functions of procurement, development, maintenance, and utilization of labor so that (1) the purpose for which the association is established and achieved efficiently and effective, (2) the goals of all employees are served to an optimal level, (3) the goals of the community are taken care of and served well.

Human resource management can be defined as a process and effort to develop, motivate, and evaluate the overall human resources needed by the company in achieving its objectives. This understanding includes starting to choose anyone who has the qualifications and suitable to occupy a position in an organization (the right man on the right place) as required by an institution or organization to how to make this qualification can be maintained even increased and developed from time to time. Because human resource management is an ongoing process, in line with the education process, attention to human resources can have a special place in educational organizations. In the company's organizational structure (as a comparison with educational institutions), especially medium and large companies, in addition to the chief director, the part responsible and functioning as managing human resource affairs is the human resources department, or commonly known asthe personnel part, so from that understanding I can analyze that human resource management is a process in which the process must develop, motivate, and evaluate the overall human resources so that a company can achieve its goals or objectives.

In general, what is meant by human resources is: a. Human resources are people who work in an organizational environment (often referred to as personnel, labor, employees or employees) b. Human resources are human potential as the activator of an organization in realizing its existence. c. Human resources are potentials and are assets and function as capital (non-material / non-financial) in the organization, which is realized as physical and 
non-physical potential in realizing the existence of the organization. Human resource development is an effort to develop the quality or ability of human resources through the process of planning education, training and management of personnel or employees to achieve an optimal result (Notoatmodjo in Sulasmi, 2020)

Basically, the function of the personnel department is to plan the concept of extension, development and improvement of the quality of human resources needed by the company. Policies relating to labor regulations, recruitment qualifications, and career development from sending labor to attend training to continuing studies, incentive programs or bonuses for labor are the main functions of this personnel. So from this understanding I can analyze that management is a process to improve a company which here must involve its workforce for labor policy itself which includes qualifications, estimates and developers for the process of activities both managing, managing, and planning in order to facilitate the achievement of goals that have been set by utilizing existing resources. In addition, human resource management (HR) is part of management. Therefore, general management theories form the basis of the discussion. Management (HR) focuses its discussion more on regulating the role of humans in realizing optimal goals. This regulation covers the problems of planning, organizing, directing, controlling, procuring, developing, compensating, integrating, maintaining, disciplining, and terminating workers to help realize the goals of the organization / institution, employees, and the community. Thus it is clear that human resource management (HR) is a process starting from planning, organizing, directing, controlling, procuring, developing, compensating, integrating, maintaining, disciplining, and lying off workers to help realize the goals of the organization / institution, employees, and society, all of which are processes that have a large role in achieving the desired goals.

The functions of human resource management include planning, organizing, mobilizing, controlling, procuring, developing, compensating, integrating, maintaining, disciplining, and terminating company needs in helping the realization of goals. (a) Organizing, is an activity to organize all employees by determining the division of labor, work relations to achieve goals. (b) Directing (directing), is the activity of directing all employees, so they want to work together and work effectively and efficiently in helping the achievement of company, employee, and community goals. (c) Control (controlling), is the activity of controlling all employees, so that they comply with company regulations and work according to plan. (d) Procurement (procurement), is the process of withdrawal, selection, placement, orientation, and induction to get employees in accordance with company needs. (e) Development (development), is the process of improving technical, conceptual, and moral skills of employees through education and training. The education and training provided must be in accordance with current and future employment needs. (f) Compensation (compensation), is the provision of direct and indirect services, money or goods to employees as compensation for services provided to the company. (g) Integration (integration), is an activity to unite the interests of the company and the needs of employees, so as to create harmonious and mutually beneficial cooperation. (h) Maintenance (maintenance), is an activity to maintain or improve the physical, mental, and loyalty of employees, so that they will continue to work together until retirement. (i) Discipline, is the most important function of management of human resources and the key to the realization of goals because without good discipline it is difficult to realize maximum goals. Dismissal (separation), is the termination of a person's employment relationship from a company.

\subsection{Scope of HR Management}

Human resource management (HR) is part of management. Therefore, general management theories form the basis of the discussion. HRM is more focused discussion 
about regulation of the role of humans in realizing optimal goals. This regulation covers the problems of planning, organizing, directing, controlling, procuring, developing, compensating, integrating, maintaining, disciplining, and terminating workers to help realize the goals of the organization / institution, employees, and the community. The following are the scope of HR management in SBM which includes: Employee planning, Employee planning is an activity to determine employee needs, both quantitatively and qualitatively for the present and the future. A good and precise personnel plan requires complete and clear information about the work or tasks that must be performed in the organization. Therefore, before preparing a plan, job analysis and job analysis are carried out to obtain a job description. This information is very helpful in determining the number of employees needed, and also to produce job specifications. This position specification provides an overview of the minimum quality of employees that can be accepted and who need to carry out work as it should. It can be concluded that the human resource planning process is a way to set goals and implementation guidelines and is the basis for employee control.

\section{Discussion}

\subsection{The Purpose of Human Resource Planning}

The following are some of the objectives of human resource planning which include: (a) to determine the quality and quantity of employees who will fill all positions in the organization / institution. (b) To guarantee the availability of labor now and in the future, so that every job there is someone who does it. (c) To avoid miss management and overlapping in the implementation of tasks. (d) To facilitate coordination, integration, and synchronization so that work productivity increases. (e) To avoid or overburden employees. To be a guideline in determining the program of withdrawal, selection, development, compensation, integration, maintenance, discipline, and dismissal of employees.

\subsection{Human Resource Planning Procedure}

The following are some human resource planning procedures which include: (a) clearly define the quality and quantity of human resources needed. (b) Collecting data and information about HR. (c) Grouping data and information and analyzing it. (d) Establish several alternatives.(e) Choose the best from the available alternatives into a plan. (f) Inform employees of the plan to be realized. With the established procedures, it is expected that in the process of human resource planning avoiding unwanted mistakes.

\subsection{Procurement of Employees}

Employee procurement is an activity to meet the needs of employees at an institution, both in number and quality. To get employees according to their needs, recruitment activities are carried out, which is an effort to find and get as many prospective employees who meet the requirements as possible, to then be selected the best and qualified candidates. For this purpose, selection is needed, through oral, written, and practical examinations. But sometimes, in an organization, the procurement of employees can be brought in internally or from within the organization, whether through promotion or transfer. This is done if the formation is empty a bit, while in other parts there are excess employees or are already prepared. Procurement of employees must be based on what principles are new, what does it mean we must first determine the jobs based on job descriptions. Who does it mean we are just looking for the right people to occupy the position based on job specifications. Recruitment of prospective employees should be done well, so that employees are accepted in accordance with the needs of the work to be done. 
The following is the process or steps taken in the procurement of employees which include: (a) Forecasting workforce needs is intended so that the amount of workforce needs of the present and future in accordance with the workload, vacancies can be avoided and all work can be done. (b) Recruitment is the process of finding and binding workers to get a number of applicants from various sources, according to the qualifications required by an organization or institution. (c) Selection is the first effort that must be done by organizations / institutions to get qualified and competent employees who will serve and do all the work in the organization / institution. The selection must be conducted honestly, carefully, and objectively so that the employees who are accepted are truly qualified to hold positions and carry out the work, so that coaching, developing, and managing employees become easier. (d) Employee placement, orientation, and induction is a follow-up to selection, which is to place prospective employees accepted (pass the selection) in positions / jobs that require it and at the same time delegate authority to that person. Appropriate employee placement is one of the keys to obtaining optimal work performance from every employee in addition to work morale, creativity and initiative will also develop. Orientation or introduction for each new employee must be made to state that they are truly accepted with open arms as employees who will work together with other employees in the organization / institution. With the orientation can be overcome doubts, awkwardness, and new employees arise confidence in doing their work. Employee induction is an activity to change the behavior of new employees so they adjust to the rules of organization / institution. Induction is basically the job of the direct supervisor of the employee concerned so that the new employee realizes that he must obey the rules of the organization / institution and do his duties properly. It can be concluded that the procurement of employees includes the process of withdrawal, selection, placement, orientation and induction to get effective and efficient employees to help achieve the goals of the organization / institution.

\subsection{Employee Development and Development}

The organization always wants its personnel to carry out their duties optimally and contribute all their abilities to the interests of the organization, and work better from day to day. Besides that, the employee himself, as a human being, also needs improvement and improvement in him, including in his duties. In this regard, the function of developing and developing employees is a function of managing personnel that is absolutely necessary, to improve, maintain and improve employee performance. This coaching and development activity does not only concern the ability aspect, but also involves the career of the employee. Employee development is considered increasingly important because of the demands of work or position, as a result of technological advances and increasingly intense competition among similar organizations / institutions. Each organization / institution personnel is required to be able to work effectively, efficiently, and the quality and quantity of their work is good so that the competitiveness of the organization / institution is greater. This development is carried out for non-career and career purposes for employees (new or old) through training and education, It can be concluded that the development and development of employees (education and training) needs to be done by each organization / institution because it will provide benefits to the organization / institution, employees, and the consumer community.

\subsection{Promotion and Mutation}

Promotion is a move that increases employee authority and responsibility to a higher position in an organization so that the obligations, rights, status, and income are even greater. Promotion means that there is trust and recognition regarding the ability and ability of the employee concerned to occupy a higher position. That way employees will be encouraged to 
work hard, be enthusiastic, be disciplined, and achieve work so that the goals of the organization / institution can be optimally achieved. One of the follow-up actions taken from the results of employee performance appraisal is employee mutation. Because the employee performance appraisal will be known employee skills in completing job descriptions that are charged to him. This mutation must be based on the achievement index that can be achieved by relevant employee. It can be concluded that mutations are included in the employee development function, because the aim is to improve work efficiency and effectiveness in organizations / institutions. After obtaining and determining the prospective employee to be accepted, the next activity is to make the prospective employee become a legitimate member of the organization so that he has rights and obligations as a member of the organization / institution. In Indonesia, for civil servants, promotions or first appointments are usually appointed as civil servants with a probation period of one or two years, then take pre-service training and after graduation are appointed full civil servants. After the appointment of employees, the next activity is placement or assignment.

\subsection{Dismissal of employees}

Termination is the termination of employment of an employee of an employee with an organization / institution. With dismissal, it means the end of employee work engagement with the organization. Dismissal of employees is a personnel function that causes the release of organizations and personnel from the rights and obligations as a workplace institution and as an employee. In relation to education staff in schools, especially Civil Servants the reasons for terminating these employees can be grouped into three types, namely: (a) Termination at own request. (b) Dismissal by the department and the government, (c) Termination of other causes.Dismissal at the request of the employee himself, for example due to a change of employment aimed at improving the lot Dismissal by the department or government can be done for the following reasons: (a) The employee concerned is incompetent and does not have the ability to carry out his duties properly. (b) Streamlining or simplifying the organization. (c) Rejuvenation, usually employees who are 55 years old and are entitled to retire must be dismissed within one year. (d) Not healthy spiritually and physically so that they cannot carry out their duties properly. (e) Committing an offense so that he is sentenced to prison or confinement. (f) Breaking a civil servants oath or promise.

\subsection{Compensation}

Compensation is a remuneration provided by the organization to employees, which can be valued in money and has a tendency given permanently. Provision of compensation other than in the form of salary can also be in the form of benefits, housing facilities, vehicles, and others. This compensation is no longer seen as satisfying material needs but has been linked to human dignity and dignity.

\subsection{Employee Assessment}

To see whether employees who are trained and developed benefit from what they do, it is necessary to evaluate or evaluate their achievements. Work performance is the result of quality and quantity of work achieved by an employee in carrying out their duties in accordance with the responsibilities given to him. For the assessment of education personnel is focused on individual achievement and participation in school activities. For employees, assessment is useful as feedback on various things, such as ability, fatigue, lack, and potential which in turn is useful for determining goals, paths, plans, and career development. For schools, the results of performance appraisal of education staff are very important in making various decisions, such as identification of school program needs, acceptance, selection, 
introduction, placement, promotion, reward systems, and other aspects of the overall effective process of human resources.

It can be concluded that absolute employee assessment must be done to find out the achievements that each employee can achieve. The results of the assessment can be used by organizations / institutions in determining further policy actions.

In the field of educators and education personnel, school education units carry out programs with the following management standards: (1) Schools / madrasas arrange educational empowerment programs and education personnel. (2) Educator and educational empowerment program: (a) Compiled by taking into account the standards of educators and education personnel; (b) Developed in accordance with the conditions of the school / madrasas including the distribution of tasks, overcome when there is a shortage of personnel, determine the reward system, and professional development for each educator and education staff and apply it professionally, fairly, and openly.

1. The appointment of additional educators and education staff is carried out based on the provisions stipulated by the administration of schools / madrasas.

2. Schools / madrasas need to support efforts:

a. Promotion of educators and education personnel based on the principles of expediency, appropriateness, and professionalism;

b. Development of education and education personnel who are systematically identified according to individual aspirations, curriculum needs and schools / madrasas;

c. Placement of education staff is adjusted to the needs of both the number and qualifications by setting priorities;

d. The transfer of educational staff from one position to another is based on an analysis of the position followed by the orientation of the task by the highest school / madrasah leadership which is carried out after four years, but can be extended based on reasons that can be accounted for, while for additional educational staff there is no mutation.

3. Schools / madrasas utilize:

a. School / madrasah principals carry out their duties and responsibilities as leaders of school / madrasah management;

b. Deputy Principal of SMP / MTS carries out their duties and responsibilities as an assistant to the principal of the school / madrasa.

c. Deputy head of SMA / SMK, MA / MAK in the field of curriculum performs their duties and responsibilities as an assistant to the head of the school / madrasah in managing the curriculum field;

d. Deputy head of SMA / SMK, MA / MAK in the infrastructure sector carries out its duties and responsibilities as an assistant to the school principal / madrasa in managing infrastructure;

e. Deputy Principal of SMA / SMK, MA / MAK in the field of students carrying out their duties and responsibilities as an assistant to the principal of the school / madrasah in managing students;

f. Deputy Head of Vocational School for Industrial Relationsindustry world;

g. The teacher carries out his duties and responsibilities as a learning agent that motivates, facilitates, educates, guides, and trains students so that they become qualified human beings and are able to actualize their human potential optimally;

h. Counselors carry out their duties and responsibilities in providing guidance and counseling services to students; 
i. The trainer / instructor carries out his duties and responsibilities providing technical training to students in training activities;

j. Library staff carry out their duties and responsibilities implementing the management of learning resources in the library;

k. Laboratory personnel carry out their duties and responsibilities to help teachers manage practical activities in the laboratory;

1. Learning resource technicians carry out their duties and responsibilities in preparing, maintaining, improving learning facilities and infrastructure;

m. Administrative staff carry out their duties and responsibilities in carrying out administrative services;

n. Cleaning staff carry out their duties and responsibilities in providing environmental cleaning services.

With the stipulation of the standard implementation of the management program of educators and education, schools have guidelines in implementing and developing programs that have been prepared by the school. With this case the principal's job as a manager of human resources (HR) is not an easy job because the principal is required to work on the management of educational staff to help smooth the SBM in the school they lead.

\section{Conclusion}

Human resources (HR) are important aspects in every activity in an institution or organization. Human resources (HR) can function optimally if managed properly. Therefore management is needed. Human resource management is a very important aspect in the education process in general. Therefore functions in the management of human resources must be carried out optimally so that the needs relating to individual, corporate, organizational or institutional goals can be achieved. Human resource management (HR) is a process related to the implementation of management functions or human resource management which is directly submitted to the school education unit to be developed in accordance with the potential of the school. The scope of human resource management (HR) includes (1) employee planning, (2) employee procurement, (3) employee development and development, (4) promotion and transfer, (5) employee dismissal, (6) compensation and (7) employee evaluation. All of that needs to be done properly and correctly so that what is expected can be achieved, namely the availability of education staff needed with appropriate qualifications and abilities and can carry out good and quality work.

\section{References}

Amirullah and HarisBudiyono. (2004). Introduction to Management. Malang: Science Graha. AzharArsyad. (2002).Fundamentals of Management, (Yogyakarta: Student Library. Amirullah and HarisBudiyono. (2004). Introduction to Management, (Malang: Grahallmu). Ara Hidayat and Imam Machali. (2010). Educational Management: Concepts, Principles and Applications in Managing Schools and Madrasas, (Yogyakarta: EDUCA Library), Awarmayanti. (2013). Human Resource Management. Bandung: RefikaAditama DadangSuhardan. (2011). Et al, Educational Management, (Bandung: Alfabeta) DjonyHerfan. (1999). The Role of HR in Implementation, (Jakarta: Pt Grasindo) Ernie Trisnawati. (2005). Introduction to Management, (Jakarta: Kencana) E. Mulyasa. (2012). School Based Management. Bandung: Teen Rosdakarya. 
FitriOviyanti, et al. (2011). School Based Management (SBM), (Palembang)

Hasibuan, Malayu S.P.(2013). Human Resource Management.Jakarta: Earth Literacy.

Herfan, Djony. (1999). Role of HR in Implementation. Jakarta: PT Grasindo.

Husaini Usman. (2011). Management Theory, Practice, and Educational Research, (Jakarta: Earth Literacy)

Made Pidarta. (1988). Indonesian Education Management, (Jakarta: Melton Putra),

Mulyasa. (2009). Implementation of Teacher and School Principal Education Unit Level Curriculum,(Jakarta: BumiAksara).

Sagala, Syaiful.(2013) Understanding Educational Organizations. Bandung: CvAlfabeta

Sondang. (1997). Management Audit. Jakarta: BumiAksaraSulistyorini. 2009 Management of Islamic Education. Yogyakarta: TerasSumiharti, Yati. 1997. Management. publisher: Erlangga. Teams of Educational Administration Lecturers at the Indonesian University of Education, Education Management, (Bandung: Alfabeta).

Sulasmi, E. (2020). The Development Strategy of Human Resources Management In Children's Social Welfare Institution (LKSA) (Case Study in LKSA AL-Mubaraak Orphanage Bengkulu). Budapest International Research and Critics Institute-Journal (BIRCI-Journal). P. 562-569.

Wisdom. (2011). Management of Education. Bandung: A loyal library of Kadarisman. 2013. Management of Human Resource Development. Jakarta: 